\title{
Interactions of protein levels fed to Holstein cows pre- and postpartum on productive and metabolic responses
}

\author{
T. Amirabadi Farahani, ${ }^{1 *}$ H. Amanlou, ${ }^{1}$ N. E. Farsuni ${ }^{1 *}$ and M. Kazemi-Bonchenari ${ }^{2}$ \\ ${ }^{1}$ Department of Animal Science, University of Zanjan, Zanjan, Iran 45371-38791 \\ ${ }^{2}$ Department of Animal Science, Faculty of Agriculture and Natural Resources, Arak University, 38156-8-8349, Arak, Iran
}

\section{ABSTRACT}

The objective of this study was to examine the interaction between levels of dietary crude protein $(\mathrm{CP})$ pre- and postpartum on feed intake, performance, and metabolic status of dairy cows with a 14-d close-up experimental period. Forty multiparous Holstein cows were blocked by expected calving date and previous lactation milk yield at $-14 \mathrm{~d}$ relative to expected calving and randomly allocated to receive either a $12.5 \%$ CP diet with $3.3 \%$ rumen undegraded protein (RUP; 12 pre) or a $15.2 \%$ CP diet with $5 \%$ RUP (15pre) based on dry matter (DM). From d 1 to 21 postpartum, cows within each prepartum group were randomly assigned to receive either a $16.1 \% \mathrm{CP}$ diet with $4.9 \%$ RUP (16post) or a $18.6 \% \mathrm{CP}$ diet with $6.8 \%$ RUP (19post) based on DM. The experiment was conducted as a split-plot design, with $\mathrm{CP}$ prepartum being the whole-plot factor and CP postpartum as the subplot factor. Diets were similar in net energy for lactation, and CP levels were increased by replacing grain with a combination of corn gluten meal and fish meal. In prepartum, cows fed the 15pre diet tended to consume more DM than cows fed the 12pre diet (9.65 vs. $9.30 \mathrm{~kg} / \mathrm{d})$. Except for blood urea nitrogen (BUN) concentration, no other blood metabolite in prepartum was affected by diets. The interaction between pre- and postpartum CP levels showed that elevating dietary $\mathrm{CP}$ from 16post to 19post increased DM intake (15.20 vs. $17.67 \mathrm{~kg} / \mathrm{d})$ and milk yield ( 35.16 vs. $40.26 \mathrm{~kg} / \mathrm{d}$ ) in 12 pre cows but not in 15pre cows. Milk fat, protein, and lactose contents were not affected by the interaction between pre- and postpartum CP levels. Feeding 19post compared with 16post increased milk protein (1.28 vs. $1.08 \mathrm{~kg} / \mathrm{d})$ and lactose $(1.86$ vs. $1.61 \mathrm{~kg} / \mathrm{d})$ yields in 12 pre cows, where-

\footnotetext{
Received February 11, 2018.

Accepted July 5, 2018.

*Corresponding authors: T.Farahani@znu.ac.ir and N.E.Farsuni@ gmail.com
}

as this effect was not observed in 15pre cows. Milk urea nitrogen was elevated when dietary CP increased from 16 post to 19 post in 15 pre cows (12.98 vs. $14.84 \mathrm{mg} / \mathrm{dL}$ ) but not in 12pre cows. The concentrations of BUN were greater in 19post cows than in 16post cows for both 12 pre (16.31 vs. $13.81 \mathrm{mg} / \mathrm{dL}$ ) and 15pre (18.44 vs. $14.71 \mathrm{mg} / \mathrm{dL})$ cows. The 19post cows had lower serum fatty acids than 16post cows (0.65 vs. $0.96 \mathrm{mmol} / \mathrm{L})$ in 12 pre but not in 15pre. However, a reduction in serum aspartate aminotransferase (AST) concentration was observed in 19post cows compared with 16post cows (68.30 vs. $98.24 \mathrm{U} / \mathrm{L})$ when cows were fed 12pre. For cows fed 15pre, those fed 19post had higher serum AST levels than those fed 16 post (86.61 vs. $67.74 \mathrm{U} / \mathrm{L}$ ) during $21 \mathrm{~d}$ of lactation. Body weight and body condition score changes were not affected by interactive effects between pre- and postpartum CP levels, but 19post cows tended $(-0.30$ vs. -0.45$)$ to have smaller body condition score losses than 16post cows when fed the 12 pre diet. Overall, increasing dietary $\mathrm{CP}$ postpartum from 16 to $19 \%$ DM improved performance and metabolic status of cows fed $12 \% \mathrm{CP}$ prepartum. The lack of responses to increased dietary $\mathrm{CP}$ postpartum in cows fed $15 \% \mathrm{CP}$ prepartum suggests that dietary CP postpartum could decrease to $16 \%$ DM when cows are fed higher dietary CP prepartum.

Key words: interaction, protein, performance, transition cow

\section{INTRODUCTION}

During the transition period, cows experience negative nutrient balance due to decreased DMI concomitant with increased demands of nutrients for fetal growth and milk production (NRC, 2001; Osorio et al., 2013). Diminished DMI in transition cows can exacerbate decreases in MP supply to the small intestine and consequently negative protein balance (NPB). Although some studies (van der Drift et al., 2012) have indicated that protein mobilization from muscle might occur before fat mobilization, NPB has received less research attention than negative energy balance dur- 
ing the transition period. Amirabadi Farahani et al. (2017) evaluated the effects of shortening the close-up period (from 21 to $10 \mathrm{~d}$ ) combined with feeding different $\mathrm{CP}$ levels on performance and metabolic status of dairy cows. They reported that multiparous cows benefited from a shortened close-up period, and feeding a $15 \% \mathrm{CP}$ prepartum diet during the close-up period increased DMI and milk yield and improved the metabolic status of postpartum cows. Likewise, Robinson et al. (2001) found no negative effect of shortened close-up period on milk production or reproduction factors in multiparous cows, and reported an optimal close-up length of 9 to 12 d for primiparous cows. Van Saun (1993) reported that the prevalence of clinical ketosis was lower for cows fed 1,300 g/d than for cows fed 1,100 $\mathrm{g} / \mathrm{d}$ of MP over the prepartum period. Many studies evaluating the effects of additional protein supply in the postpartum period on performance and metabolism of dairy cows have been conducted at $>21$ DIM (Lee et al., 2015; Giallongo et al., 2016; Barros et al., 2017). A few studies (Larsen et al., 2014; Amanlou et al., 2017; Carder and Weiss, 2017) have focused on increased protein supply in immediate postpartum cows. Larsen et al. (2014) found that additional MP supply using abomasal casein infusion increased milk production and milk protein yield from 1 to 29 DIM. Likewise, Amanlou et al. (2017) reported that elevating dietary CP from 16 to $19 \%$ of DM using RUP supplements increased DMI and milk yield and improved metabolic status of cows from 1 to 21 DIM. However, Carder and Weiss (2017) did not observe any positive effects on DMI and milk yield when dietary CP levels increased from 16.5 to $18.5 \%$ of $\mathrm{DM}$ in the first 3 wk of lactation. Although Lean et al. (2013) suggested that an increase in dietary protein content prepartum might decrease the effects of additional protein supply postpartum, no study to date has examined the interaction between the levels of dietary $\mathrm{CP}$ fed to Holstein cows pre- and postpartum. Our hypothesis was that there is an interaction between the levels of dietary $\mathrm{CP}$ fed to Holstein cows pre- and postpartum on DMI, milk yield, and metabolic status of dairy cows. To address these interactive effects on metabolic status, we evaluated serum metabolites from cows fed experimental diets. We measured concentrations of total protein, albumin, and BUN (protein status); fatty acids, BHB, and glucose (energy status); creatinine and creatine kinase (muscle mass catabolism); bilirubin, AST, and cholesterol (liver status); and calcium and magnesium (mineral status) of periparturient calving cows. Therefore, our objective was to evaluate the effects of 2 prepartum diets differing in $\mathrm{CP}$ and postpartum supplementation of $\mathrm{CP}$ using RUP sources for $3 \mathrm{wk}$ of lactation on DMI, milk yield, and metabolic status of multiparous Holstein dairy cows with a 14-d close-up experimental period.

\section{MATERIALS AND METHODS}

\section{Feeding, Experimental Design and Management of Cows}

The present study was carried out at FKA dairy farm (FKA Animal Husbandry and Agriculture Co., Isfahan, Iran). Forty multiparous Holstein cows were enrolled in the study $60 \mathrm{~d}$ before expected calving. During the faroff period, cows were group-fed the herd's far-off diet (Table 1) for ad libitum intake once daily $(0930 \mathrm{~h})$ from -60 to $-14 \mathrm{~d}$ relative to parturition. Cows were then blocked by expected calving date and previous lactation milk yield at $14 \mathrm{~d}$ before expected calving date. Cows within each block were randomly allocated to one of the following diets: (1) $12.5 \% \mathrm{CP}$ diet with $3.3 \%$ RUP (12pre), according to NRC (2001); or (2) $15.2 \%$ CP diet with 5\% RUP (15pre) based on DM (Table 1) during the shortened close-up period (Amirabadi Farahani et al., 2017). At enrollment, cows averaged $13,106 \pm 179 \mathrm{~kg}$ of milk (previous lactation) and 2.5 \pm 0.5 lactations. During the prepartum period, diets were fed twice a day at 0800 and $1600 \mathrm{~h}$, and the actual days that cows were on the prepartum diets were 8.5 $\pm 1.2 \mathrm{~d}$ (mean $\pm \mathrm{SD}$ ). From d 1 to 21 postpartum, cows within each prepartum group were randomly assigned to receive either a $16.1 \%$ CP diet with $4.9 \%$ RUP (16post) or a $18.6 \% \mathrm{CP}$ diet with $6.8 \%$ RUP (19post) based on DM (Table 1). The experiment had a split-plot arrangement with dietary $\mathrm{CP}$ prepartum (12pre and 15pre) as the whole-plot factor and dietary CP postpartum (16post and 19post) as the subplot factor. The $\mathrm{NE}_{\mathrm{L}}$ values of the pre- and postpartum diets were 1.66 and $1.69 \mathrm{Mcal} / \mathrm{kg}$ of $\mathrm{DM}$, respectively, and $\mathrm{CP}$ levels were increased by replacing grain with RUP sources (corn gluten meal and fish meal).

When cows showed primary signs of calving, they were moved to maternity pens; calf weight and firstmilking colostrum were recorded immediately postpartum. Calving difficulty score (CDS) was determined using a 5 -point scale $(1=$ no calving problem, $2=$ minor problem, $3=$ needed assistance, $4=$ considerable force, 5 = caesarian; Park et al., 2002).

All cows received the postpartum diets (Table 1) thrice a day at 0900, 1700, and $2300 \mathrm{~h}$. Cows were milked daily at 0800,1600 , and $2200 \mathrm{~h}$. In the pre- and postpartum periods, cows were housed in individual stalls bedded with sand, had free access to water, and were fed a TMR ad libitum to achieve 5 to $10 \%$ orts. Experimental diets were formulated using the NRC 
(2001) model for pre- and postpartum cows (Tables 1 and 2).

\section{Sampling and Data Collection}

During the prepartum period, DMI of individual cows was determined daily from $-14 \mathrm{~d}$ relative to expected calving until 21 DIM. Each animal was required to have at least $7 \mathrm{~d}$ of prepartum intake data to remain in the study. Samples of TMR and orts were taken twice a week for DM measurement, and were dried at $60^{\circ} \mathrm{C}$ for $48 \mathrm{~h}$, and then composited by week and treatment. Individual feed ingredients were sampled weekly and frozen at $-20^{\circ} \mathrm{C}$ for later chemical analysis. Samples of TMR, orts, and feed ingredients were ground through a 1-mm screen and analyzed for Kjeldahl N (AOAC, 1990; method 984.13), ether extract (AOAC, 1990; method 920.39), ash (AOAC, 1990, method 942.05), ADF (AOAC, 1990; method 973.18), and NDF (Van Soest et al., 1991). The composition of other components of experimental diets (i.e., $\mathrm{NE}_{\mathrm{L}}$, RDP, RUP, minerals) was estimated using NRC (2001).

Cows were weighed at $-14,-1,0$, and $21 \mathrm{~d}$ relative to expected calving, and BW loss due to calving was calculated as BW at calving (calving day) minus the last weight before calving. Cows were scored for body

Table 1. Feed ingredients of the diets fed cows during far-off, prepartum, and postpartum periods (\% of DM)

\begin{tabular}{|c|c|c|c|c|c|}
\hline \multirow[b]{2}{*}{ Ingredient } & \multirow[b]{2}{*}{ Far-off } & \multicolumn{2}{|c|}{ Prepartum $^{1}$} & \multicolumn{2}{|c|}{ Postpartum $^{2}$} \\
\hline & & 12pre & 15pre & 16post & 19post \\
\hline Legume forage hay, mature ${ }^{3}$ & 26.80 & 18.76 & 18.76 & 20.30 & 20.30 \\
\hline Corn silage, normal ${ }^{4}$ & 44.27 & 41.00 & 41.00 & 25.50 & 25.50 \\
\hline Barley grain, rolled $^{5}$ & 5.00 & 8.00 & 5.00 & 11.00 & 5.55 \\
\hline Corn grain, ground, dry $^{6}$ & 5.00 & 15.45 & 12.50 & 16.85 & 16.85 \\
\hline Cottonseed, whole with lint ${ }^{7}$ & - & 5.0 & 5.0 & 6.60 & 6.60 \\
\hline Canola meal ${ }^{8}$ & 4.33 & 1.60 & 1.60 & - & - \\
\hline Soybean meal, solvent ${ }^{9}$ & 4.00 & 6.00 & 6.00 & 9.50 & 9.50 \\
\hline Fish meal ${ }^{10}$ & - & - & 3.00 & 1.11 & 3.89 \\
\hline Corn gluten meal ${ }^{11}$ & - & - & 3.00 & 1.00 & 3.65 \\
\hline Extruded full-fat soybean ${ }^{12}$ & - & - & - & 4.50 & 4.50 \\
\hline Rice $b_{r a n}{ }^{13}$ & 8.90 & - & - & - & - \\
\hline Salt & 0.21 & - & - & 0.30 & 0.30 \\
\hline Calcium carbonate & 0.53 & 1.35 & 1.35 & 0.67 & 0.67 \\
\hline Dicalcium phosphate & 0.11 & - & - & 0.30 & 0.30 \\
\hline Magnesium oxide & 0.11 & 0.15 & 0.15 & 0.24 & 0.24 \\
\hline Magnesium sulfate & - & 0.85 & 0.80 & - & - \\
\hline Calcium chloride & - & 0.45 & 0.45 & - & - \\
\hline Bentonite & 0.32 & 0.47 & 0.47 & 0.33 & 0.33 \\
\hline Biotin & - & 0.004 & 0.004 & 0.004 & 0.004 \\
\hline Selenium & - & 0.004 & 0.004 & 0.004 & 0.004 \\
\hline Choline chloride & - & 0.37 & 0.37 & 0.24 & 0.24 \\
\hline Monensin & - & 0.01 & 0.01 & 0.01 & 0.01 \\
\hline $\mathrm{NaHCO}_{3}$ & - & - & - & 1.10 & 1.10 \\
\hline Mineral premix ${ }^{14}$ & 0.21 & 0.27 & 0.27 & 0.23 & 0.23 \\
\hline Vitamin premix $^{15}$ & 0.21 & 0.27 & 0.27 & 0.23 & 0.23 \\
\hline
\end{tabular}

${ }^{1}$ Diets fed from $14 \mathrm{~d}$ before parturition until calving; $12 \mathrm{pre}=12.5 \% \mathrm{CP}$ and 15 pre $=15.2 \% \mathrm{CP}$ based on DM.

${ }^{2}$ Diets fed during first $3 \mathrm{wk}$ of lactation; 16 post $=16.1 \% \mathrm{CP}$ and 19 post $=18.6 \% \mathrm{CP}$ based on DM.

${ }^{3}$ Contained $85.0 \%$ DM, 50.0\% NDF, 40.5\% ADF, and 14.0\% CP (DM basis).

${ }^{4}$ Contained $24.0 \%$ DM, $45.0 \%$ NDF, 30\% ADF, and 8.8\% CP (DM basis).

${ }^{5}$ Contained $11.3 \% \mathrm{CP}$ (DM basis).

${ }^{6}$ Contained $8.2 \% \mathrm{CP}$ (DM basis).

${ }^{7}$ Contained $91.0 \%$ DM, 50.8\% NDF, 40.0\% ADF, and 19.5\% CP (DM basis).

${ }^{8}$ Mechanically extracted. Contained $38.0 \%$ CP (DM basis).

${ }^{9}$ Contained $43.0 \%$ CP (DM basis).

${ }^{10}$ Contained $54.0 \%$ CP (DM basis).

${ }^{11}$ Contained 57.0\% CP (DM basis).

${ }^{12}$ Contained $38.0 \%$ CP (DM basis).

${ }^{13}$ Contained $14.0 \%$ CP (DM basis).

${ }^{14}$ Premix contained $0.32 \mathrm{~g}$ of $\mathrm{Co} / \mathrm{kg}, 13.3 \mathrm{~g}$ of $\mathrm{Cu} / \mathrm{kg}, 0.5 \mathrm{~g}$ of I/ $\mathrm{kg}, 0.04 \mathrm{~g}$ of Fe $/ \mathrm{kg}, 33.4 \mathrm{~g}$ of Mn/kg, $8 \mathrm{~g}$ of $\mathrm{Se} / \mathrm{kg}, 56.2 \mathrm{~g}$ of $\mathrm{Zn} / \mathrm{kg}$.

${ }^{15}$ Premix contained 1,800,000 IU of vitamin A/kg, 200,000 IU of vitamin D/kg, and 15,000 IU of vitamin E/ kg. 
Table 2. The chemical composition of diets fed cows during the far-off, prepartum, and postpartum periods (\% of DM, unless otherwise stated)

\begin{tabular}{|c|c|c|c|c|c|}
\hline \multirow[b]{2}{*}{ Component } & \multirow[b]{2}{*}{ Far-off } & \multicolumn{2}{|c|}{ Prepartum $^{1}$} & \multicolumn{2}{|c|}{ Postpartum $^{2}$} \\
\hline & & 12pre & 15pre & 16post & 19post \\
\hline $\mathrm{NE}_{\mathrm{L}}^{3}$ (Mcal/kg of DM) & 1.59 & 1.66 & 1.66 & 1.69 & 1.69 \\
\hline $\mathrm{CP}$ & 13.2 & 12.5 & 15.2 & 16.10 & 18.60 \\
\hline $\mathrm{RDP}^{3}$ & 9.3 & 9.2 & 10.2 & 11.20 & 11.80 \\
\hline $\mathrm{RUP}^{3}$ & 3.9 & 3.3 & 5.0 & 4.90 & 6.80 \\
\hline $\mathrm{MP}^{3}(\mathrm{~g} / \mathrm{kg}$ of $\mathrm{DM})$ & 83 & 80 & 101 & 102 & 119 \\
\hline NDF & 39.0 & 34.9 & 34.3 & 31.2 & 30.4 \\
\hline Forage $\mathrm{NDF}^{3}$ & 33.3 & 27.8 & 27.8 & 21.4 & 21.5 \\
\hline $\mathrm{ADF}$ & 27.1 & 23.9 & 23.8 & 21.4 & 21.3 \\
\hline $\mathrm{NFC}$ & 38.9 & 43.1 & 40.6 & 42.4 & 40.4 \\
\hline Ether extract & 3.8 & 3.6 & 3.6 & 4.4 & 4.5 \\
\hline $\mathrm{Ca}^{3}$ & 0.7 & 1.1 & 1.2 & 0.8 & 0.9 \\
\hline $\mathrm{P}^{3}$ & 0.5 & 0.30 & 0.4 & 0.4 & 0.4 \\
\hline $\mathrm{Mg}^{3}$ & 0.33 & 0.42 & 0.41 & 0.34 & 0.34 \\
\hline $\mathrm{Na}^{3}$ & 0.10 & 0.02 & 0.05 & 0.44 & 0.47 \\
\hline $\mathrm{K}^{3}$ & 1.51 & 1.26 & 1.27 & 1.30 & 1.31 \\
\hline $\mathrm{Cl}^{3}$ & 0.41 & 0.46 & 0.48 & 0.41 & 0.43 \\
\hline$S^{3}$ & 0.20 & 0.36 & 0.39 & 0.21 & 0.24 \\
\hline $\mathrm{DCAD}^{3}(\mathrm{mEq} / \mathrm{kg}$ of $\mathrm{DM})$ & 188 & -27 & -35 & 283 & 268 \\
\hline \multicolumn{6}{|l|}{ Protein supply $(\mathrm{g} / \mathrm{d})$} \\
\hline $\mathrm{RDP}$ requirement & 1,410 & 967 & 998 & 1,672 & 1,810 \\
\hline RDP supply & 1,300 & 857 & 982 & 1,806 & 2,065 \\
\hline RDP balance & -110 & -110 & -16 & +134 & +255 \\
\hline RUP requirement & 76 & 325 & 241 & 1,525 & 1,586 \\
\hline RUP supply & 542 & 301 & 482 & 794 & 1,188 \\
\hline RUP balance & +466 & -24 & +241 & -731 & -398 \\
\hline MP supply & 1,168 & 744 & 976 & 1,647 & 2,075 \\
\hline MP requirement ${ }^{4}$ & 829 & 882 & 898 & 2,256 & 2,415 \\
\hline MP balance & +339 & -138 & +78 & -609 & -340 \\
\hline \multicolumn{6}{|l|}{ Digestible AA flow $^{3}$ (g/d) } \\
\hline Lys & 82 & 54 & 65 & 112 & 131 \\
\hline Met & 24 & 16 & 21 & 33 & 41 \\
\hline Leu & 103 & 69 & 97 & 149 & 197 \\
\hline His & 26 & 17 & 21 & 37 & 45 \\
\hline
\end{tabular}

${ }^{1}$ Diets fed from $14 \mathrm{~d}$ before expected calving until calving; 12 pre $=12.5 \% \mathrm{CP}$ and $15 \mathrm{pre}=15.2 \% \mathrm{CP}$ based on DM.

${ }^{2}$ Diets fed during first 3 wk of lactation; 16 post $=16.1 \% \mathrm{CP}$ and 19 post $=18.6 \% \mathrm{CP}$ based on DM.

${ }^{3}$ All values were estimated using NRC (2001) based on actual DMI, BW, BCS, and calf weight of the cows in prepartum diets; and based on actual DMI, BW, BCS, and calf weight, milk yield, and milk composition of the cows in postpartum diets.

${ }^{4}$ Requirement in prepartum period was NRC model plus $120 \mathrm{~g} / \mathrm{d}$ MP to account for mammary growth (Bell et al., 2000).

condition using a 5-point scale with 0.25 -point increments (Edmonson et al., 1989) by 2 skilled investigators at $-14,0$, and $+21 \mathrm{~d}$ relative to expected calving. Then, BCS loss due to calving was calculated as the BCS at calving (calving day) minus the BCS at the start of the close-up period. Results from the 2 investigators were averaged and used for statistical analysis.

Milk yield of individual cows was recorded daily from 1 to 21 DIM. Milk samples from each cow were taken weekly from 3 consecutive milkings and composited in proportion to milk yield. Milk composition (fat, true protein, lactose, SCC, and urea) was determined by mid-infrared spectroscopy using a Milkoscan (CombiFoss 78110; Foss Analytical A/S, Hillerød, Denmark). The equations of NRC (2001) were used to calculate energy balance (EB) pre- and postpartum. Net energy intake $\left(\mathrm{NE}_{\mathrm{I}}\right)$ was calculated by multiplying $\mathrm{DMI}$ by $\mathrm{NE}_{\mathrm{L}}$ (Mcal) per kilogram of DM. Net energy requirement for maintenance $\left(\mathrm{NE}_{\mathrm{M}}\right)$ was calculated as $0.08 \times \mathrm{BW}^{0.75}$. Net energy requirement for pregnancy $\left(\mathrm{NE}_{\mathrm{P}}\right)$ was calculated as $[(0.00318 \times$ day of gestation -0.0352$) \times$ (calf birth weight/45)]/0.218. Net energy requirement for lactation $\left(\mathrm{NE}_{\mathrm{L}}\right)$ was calculated as $(0.0929 \times$ fat $\%$ $+0.0563 \times$ protein $\%+0.0395 \times$ lactose $\%) \times$ milk yield. The prepartum $\mathrm{EB}$ (\% of $\mathrm{NE}_{\mathrm{L}}$ requirement) was calculated as $\mathrm{EB}=\left[\mathrm{NE}_{\mathrm{I}} /\left(\mathrm{NE}_{\mathrm{M}}+\mathrm{NE}_{\mathrm{P}}\right)\right] \times 100$; and postpartum EB was calculated as $\mathrm{EB}=\left[\mathrm{NE}_{\mathrm{I}} /\left(\mathrm{NE}_{\mathrm{M}}+\right.\right.$ $\left.\left.\mathrm{NE}_{\mathrm{L}}\right)\right] \times 100$.

Protein supplies and their balances (Table 2) in pre- and postpartum diets were estimated using NRC 
(2001). The concentrations of RDP and RUP in the experimental diets were calculated using the NRC (2001) model, and the default values for all $\mathrm{N}$ fractions and digestion rates of the ingredients were used. Based upon actual information (DMI, milk yield, milk composition, $\mathrm{BW}, \mathrm{BCS}$, and calf weight) of the cows and actual CP contents of individual feed ingredients, the MP requirements were 882 and $898 \mathrm{~g} / \mathrm{d}$ in the 12pre and 15pre diets, respectively, and 2,256 and $2,415 \mathrm{~g} / \mathrm{d}$ in 16post and 19post, respectively. The MP balances were -138 and $+78 \mathrm{~g} / \mathrm{d}$ in 12 pre and 15 pre, respectively, and -609 and $-340 \mathrm{~g} / \mathrm{d}$ in 16 post and 19post, respectively. The MP requirement of cows in prepartum was the NRC model value plus $120 \mathrm{~g} / \mathrm{d}$ MP to account for mammary growth (Bell et al., 2000). Digestible AA supply (Table 2 ) from the diets was estimated using NRC (2001).

Blood samples were taken $4 \mathrm{~h}$ after morning feeding from the coccygeal vein using an evacuated tube without anticoagulant (Vacumed no additive; FL Medical, Torreglia, Italy) at $-14,-10,-7,-3$, and $-1 \mathrm{~d}$ relative to expected calving; and at $0,3,7,14$, and 21 DIM. In the prepartum period, the actual days of blood sampling $($ mean $\pm \mathrm{SD})$ were $-7.7 \pm 0.7$ and $-1.7 \pm 0.8 \mathrm{~d}$. Serum samples were collected following centrifugation at 2,500 $\times g$ for $10 \mathrm{~min}$ and stored at $-20^{\circ} \mathrm{C}$ for later analysis. Serum samples were analyzed for the concentrations of glucose (glucose oxidase-phenol 4-aminoantipyrine peroxidase method), total protein (biuret method), albumin (bromocresol green method at acidic $\mathrm{pH}$ ), BUN (Berthelot method), aspartate aminotransferase [AST; International Federation of Clinical Chemistry (IFCC) method, Bergmeyer et al. (1986)], cholesterol (cholesterol oxidase-phenol 4-aminoantipyrine peroxidase method), triacylglycerol ( glycerol-3-phosphate oxidase-phenol 4 aminoantipyrine peroxidase method), total $\mathrm{Ca}$ (o-cresolphthalein-complexone method), $\mathrm{Mg}$ (xylidyl blue method), creatine kinase (IFCC method), bilirubin (dichloroaniline method), and creatinine (Jaffe method) using commercial kits (Pars Azmoon Laboratory, Tehran, Iran). Globulin concentration was obtained as the difference between total protein and albumin. Serum concentrations of fatty acids (colorimetric method), and BHB (enzymatic method; based on 3-hydroxybutyrate dehydrogenase) were measured by using Randox Kits (Randox Laboratories Ltd., Crumlin, UK), using a serum spectrophotometer (UNICCO, 2100, Zistchemi Co., Tehran, Iran). All serum metabolites were analyzed according to references from Amanlou et al. $(2016,2017)$.

\section{Statistical Analyses}

Of the 40 cows enrolled in the study, 37 were used in the final analyses. Three animals were removed from the study because they had fewer than $7 \mathrm{~d}$ of individual feed intake for the prepartum diets. The data were analyzed using PROC MIXED of SAS (version 9.3; SAS Institute Inc., Cary, NC). Pre- and postpartum data were analyzed separately.

Prepartum data were analyzed in a complete randomized block design. For repeated-measures data, the model included fixed effects of diet, time, and diet $\times$ time interaction, and random effects of block and cows nested within block. For blood metabolites analysis, serum data at $-14 \mathrm{~d}$ relative to expected calving were included as a covariate when significant.

Postpartum data were analyzed by ANOVA according to a complete randomized block split-plot design with CP prepartum as the whole-plot factor and CP postpartum as the subplot factor. For repeated measurement data, the model included fixed effects of CP prepartum, CP postpartum, time, and all possible interactions of fixed effects with cows nested within block by $\mathrm{CP}$ prepartum by $\mathrm{CP}$ postpartum as subject. Block and block $\times \mathrm{CP}$ prepartum were included as random effects. To analyze calf birth weight, CDS, colostrum volume, and BW and BCS changes, the fixed effects of time and associated interactions were excluded from the above models. Data are reported as least squares means (LSM) and significance and trend toward significance were declared at $P \leq 0.05$ and $0.05<P \leq 0.10$, respectively, using the Tukey multiple comparison test.

\section{RESULTS AND DISCUSSION}

\section{Calving Measurements}

Increasing dietary $\mathrm{CP}$ levels in prepartum did not affect calf birth weight $(P=0.34$; Table 3$), \operatorname{CDS}(P=$ 0.33 ; Table 3 ), or colostrum volume in the first milking $(P=0.42$; Table 3$)$, similar to our previous experiment (Amirabadi Farahani et al., 2017) and others (Hook et al., 1989; Doepel et al., 2002; Adachi et al., 2006). Losses in BW $(P=0.60$; Table 3$)$ and BCS $(P=0.59$; Table 3) at calving did not differ between animals fed the prepartum 12pre and 15pre diets. These findings were supported by unchanged serum fatty acids and BHB concentrations prepartum.

\section{Prepartum Period}

$D M I, E B$, and $B W$. The effects of $\mathrm{CP}$ levels in the prepartum diets on prepartum DMI, EB, and BW change are presented in Table 4 . Compared with 12pre cows, 15pre cows tended $(P=0.07)$ to have greater DMI prepartum (9.65 vs. $9.30 \mathrm{~kg} / \mathrm{d})$. However, EB and BW change were not affected by CP levels in the prepartum diet $(P>0.10)$. Our previous experiment 
Table 3. Effects of increasing dietary CP levels prepartum on calving measurements in multiparous Holstein cows

\begin{tabular}{|c|c|c|c|c|}
\hline \multirow[b]{2}{*}{ Item } & \multicolumn{2}{|c|}{ Diet $^{1}$} & \multirow[b]{2}{*}{ SEM } & \multirow{2}{*}{$\begin{array}{c}P \text {-value } \\
\text { Diet }\end{array}$} \\
\hline & $\begin{array}{c}\text { 12pre } \\
(\mathrm{n}=19)\end{array}$ & $\begin{array}{c}15 \text { pre } \\
(\mathrm{n}=18)\end{array}$ & & \\
\hline Calf birth weight (kg) & 43.27 & 44.4 & 0.81 & 0.34 \\
\hline $\mathrm{CDS}^{2}$ & 0.99 & 1.06 & 0.04 & 0.33 \\
\hline First colostrum weight (kg) & 7.43 & 6.27 & 1.0 & 0.42 \\
\hline BW loss at calving ${ }^{3}(\mathrm{~kg})$ & -55.81 & -57.25 & 2.06 & 0.60 \\
\hline BCS loss at calving $^{4}$ & -0.31 & -0.27 & 0.05 & 0.59 \\
\hline
\end{tabular}

${ }^{1}$ Prepartum diets: 12 pre $=12.5 \% \mathrm{CP}$ and 15 pre $=15.2 \% \mathrm{CP}$ based on DM.

${ }^{2}$ Calving difficulty score (scale of 1 to 5 , where $1=$ no calving problem, $2=$ minor problem, $3=$ needed assistance, $4=$ considerable force, $5=$ caesarian; Park et al., 2002).

${ }^{3}$ The BW at calving (calving day) minus the last weight before calving.

${ }^{4}$ The BCS at calving (calving day) minus the BCS at the start of the close-up period; scoring was based on a scale 1 to 5 with 0.25 increments (Edmonson et al., 1989).

(Amirabadi Farahani et al., 2017) showed an increase in DMI of $1.2 \mathrm{~kg} / \mathrm{d}$ when dietary $\mathrm{CP}$ was increased from 12 to $15 \%$ of DM using RUP supplements. In contrast, most studies have shown no effect of supplemental protein on prepartum DMI in close-up diets (Greenfield et al., 2000; Doepel et al., 2002; Park et al., 2002). In the latter studies, the lack of response in prepartum DMI to increased dietary CP may be a result of gut fill from higher NDF in low-energy diets, inadequate RDP supply to meet microbial needs (resulting in a reduction not only in MP but also in fiber digestibility), or increasing dietary CP by RDP supplement inclusion.

Blood Metabolites. The concentrations of serum metabolites of cows fed different $\mathrm{CP}$ levels during the prepartum period are listed in Table 5 . We observed no effect of CP level in the prepartum diet on concentrations of serum metabolites and minerals $(P>0.05)$, except an increase in BUN $(P<0.01)$ in cows fed 15pre compared with those fed 12 pre. Increased BUN might be due to dietary CP content (Jonker et al., 1998), greater use of AA as an energy source by fetal tissues (Bell, 1995), or both. The results of present study are supported by previous studies (Hartwell et al., 2000; Doepel et al., 2002) that investigated the effect of increased CP in close-up diets. There was an effect of time $(P<0.01)$ on BUN: with approaching calving, BUN concentrations were reduced. This may indicate greater efficiency of AA use for maintenance and gestation, decreased protein intake, or both (Hartwell et al., 2000; Doepel et al., 2002). There was also a time effect $(P<0.01)$ on serum albumin, cholesterol, triglyceride, $\mathrm{BHB}, \mathrm{Ca}$, and $\mathrm{Mg}$ concentrations, with BHB increasing $(P<0.01)$ and other metabolites concentrations decreasing $(P<0.01)$ with approaching calving (Table 5$)$.

\section{Postpartum Period (1 to 21 DIM)}

DMI and Energy Intake. An interaction between pre- and postpartum CP levels was detected for DMI $(P=0.02$; Table 6$)$ : elevating dietary $\mathrm{CP}$ (from 16post

Table 4. Effects of increasing dietary CP levels prepartum on nutrient intake, energy balance, and BW in the prepartum period for multiparous Holstein cows

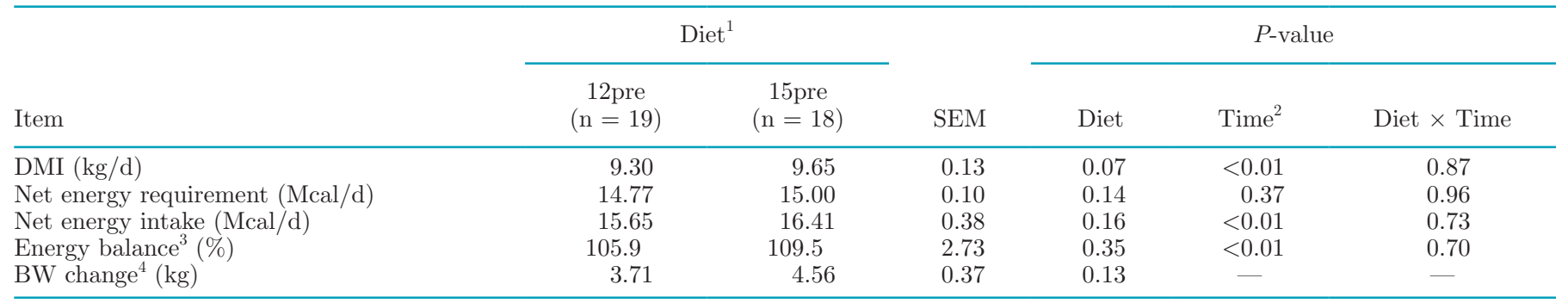

${ }^{1}$ Prepartum diets: 12 pre $=12.5 \% \mathrm{CP}$ and 15 pre $=15.2 \% \mathrm{CP}$ based on DM.

${ }^{2}$ From -7 d relative to parturition to calving.

${ }^{3}$ Percentage of $\mathrm{NE}_{\mathrm{L}}$ requirement.

${ }^{4}$ The last value before calving minus first value when on the close-up diet. 
Table 5. Effects of increasing dietary CP levels prepartum on blood metabolites in prepartum period for multiparous Holstein cows

\begin{tabular}{|c|c|c|c|c|c|c|}
\hline \multirow[b]{2}{*}{ Item } & \multicolumn{2}{|c|}{$\operatorname{Diet}^{1}$} & \multirow[b]{2}{*}{ SEM } & \multicolumn{3}{|c|}{$P$-value } \\
\hline & $\begin{array}{c}12 \text { pre } \\
(\mathrm{n}=19)\end{array}$ & $\begin{array}{c}\text { 15pre } \\
(\mathrm{n}=18)\end{array}$ & & Diet & Time $^{2}$ & Diet $\times$ Time \\
\hline Total protein $(\mathrm{g} / \mathrm{dL})$ & 7.26 & 7.18 & 0.13 & 0.67 & 0.66 & 0.90 \\
\hline Albumin $(\mathrm{g} / \mathrm{dL})$ & 3.35 & 3.46 & 0.08 & 0.36 & $<0.01$ & 0.52 \\
\hline Globulin $(\mathrm{g} / \mathrm{dL})$ & 3.90 & 3.71 & 0.15 & 0.40 & 0.44 & 0.68 \\
\hline Albumin:globulin ratio & 0.99 & 0.98 & 0.06 & 0.90 & $<0.01$ & 0.90 \\
\hline BUN (mg/dL) & 12.60 & 13.80 & 0.30 & $<0.01$ & $<0.01$ & 0.27 \\
\hline Glucose $(\mathrm{mg} / \mathrm{dL})$ & 57.64 & 58.20 & 1.64 & 0.80 & 0.75 & 0.51 \\
\hline Fatty acids (mmol/L) & 0.40 & 0.38 & 0.04 & 0.65 & 0.13 & 0.50 \\
\hline $\mathrm{BHB}(\mathrm{mmol} / \mathrm{L})$ & 0.53 & 0.50 & 0.02 & 0.41 & 0.01 & 0.87 \\
\hline Cholesterol (mg/dL) & 124 & 129 & 7.2 & 0.61 & 0.03 & 0.92 \\
\hline Triglyceride (mg/dL) & 44.76 & 41.0 & 2.4 & 0.27 & $<0.01$ & 0.63 \\
\hline $\mathrm{Ca}(\mathrm{mg} / \mathrm{dL})$ & 8.85 & 9.06 & 0.14 & 0.33 & $<0.01$ & 0.23 \\
\hline $\operatorname{Mg}(\mathrm{mg} / \mathrm{dL})$ & 1.63 & 1.70 & 0.07 & 0.40 & $<0.01$ & 0.49 \\
\hline
\end{tabular}

${ }^{1}$ Prepartum diets: 12 pre $=12.5 \% \mathrm{CP}$ and 15 pre $=15.2 \% \mathrm{CP}$ based on DM.

${ }^{2}$ From -7 d relative to parturition to calving.

to 19post) in postpartum diets increased DMI in cows fed the 12pre diet but not the 15pre diet. Differences in intake led to greater energy intake in 12pre-19post cows than in 12 pre-16post cows $(P=0.01$; Table 6$)$, but there was no difference between 15 pre-19post and 15pre-16post. These results suggest that feeding higher dietary $\mathrm{CP}$ prepartum might result in a lower requirement of CP postpartum than when fed lower dietary CP prepartum.

Most studies evaluating additional protein effects prepartum found no effect (Huyler et al., 1999; Vandehaar et al., 1999; Park et al., 2002) or even a reduction (Greenfield et al., 2000; Hartwell et al., 2000) in postpartum DMI. In contrast, others reported that feeding additional protein to cows in immediate postpartum (Amanlou et al., 2017), early (Law et al., 2009), mid (Cabrita et al., 2011; Giallongo et al., 2016), and late (Barros et al., 2017) lactation increased DMI. To our knowledge, no study has examined the interaction between pre- and postpartum CP levels. Therefore, it appears that our study is the first to examine the transition period, considering the interaction between pre- and postpartum CP levels on DMI. Increased DMI for cows fed 12pre-19post compared with 12pre-16post agrees with the hepatic oxidation theory concept (Allen et al., 2009); fatty acid concentrations were lower in 12 pre-19post than in 12 pre-16post (0.65 vs. 0.96 $\mathrm{mmol} / \mathrm{L}$; Table 7 ) but not different between 15pre19 post and 15pre-16post (0.59 vs. $0.68 \mathrm{mmol} / \mathrm{L}$; Table 7 ), which could explain higher DMI through decreased fatty acids flow to the liver in this dietary treatment.

Milk Production and Composition. We detected an interaction between pre- and postpartum CP levels on milk yield during the first 21 DIM $(P<0.01$;
Table 6). The 12pre-19post cows produced $5.1 \mathrm{~kg} / \mathrm{d}$ more milk than 12pre-16post cows but milk yield did not differ between 15pre-19post and 15pre-16post. The yield of $4 \%$ FCM tended $(P=0.1$; Table 6$)$ to be higher in cows fed 12 pre-19post than those fed 12pre-16post $(37.0$ vs. $32.09 \mathrm{~kg} / \mathrm{d})$.

The results of the present study showed that protein deficiency both pre- and postpartum negatively affected milk production in dairy cows; thus, NPB in the transition period should be given more attention. Larsen et al. (2014) and Amanlou et al. (2017) reported 7.2 and $4.7 \mathrm{~kg} / \mathrm{d}$ more milk yield, respectively, with additional protein supply during the immediate postpartum period. In contrast, Socha et al. (2005) and Carder and Weiss (2017) found no effect of feeding additional protein on milk yield postpartum. Differences in milk yield responses might be related to dietary CP levels in the close-up period; the content of $\mathrm{CP}$ was less than 15\% in Larsen et al. (2014) and Amanlou et al. (2017), thus confirming the results of the current study for the 12pre diet. Although Carder and Weiss (2017) did not present any information on the chemical composition of their close-up diet, in Socha et al. (2005), cows received $15.6 \% \mathrm{CP}$ in the close-up diet, supporting our results for the 15pre diet. Overall, our findings suggest that higher dietary CP prepartum lessens the effect of dietary CP postpartum, whereas lower dietary CP prepartum accentuates the response to postpartum CP.

In addition, increased milk yield might be due to increased supply of AA (especially Lys, Met, Leu, and His) to the mammary gland because of increased DMI for cows fed 12pre-19post compared with 12pre-16post. Giallongo et al. (2015) did not observe any effect on milk yield when cows were fed diets with MP deficiency 
INTERACTIONS OF PROTEIN LEVELS PRE- AND POSTPARTUM

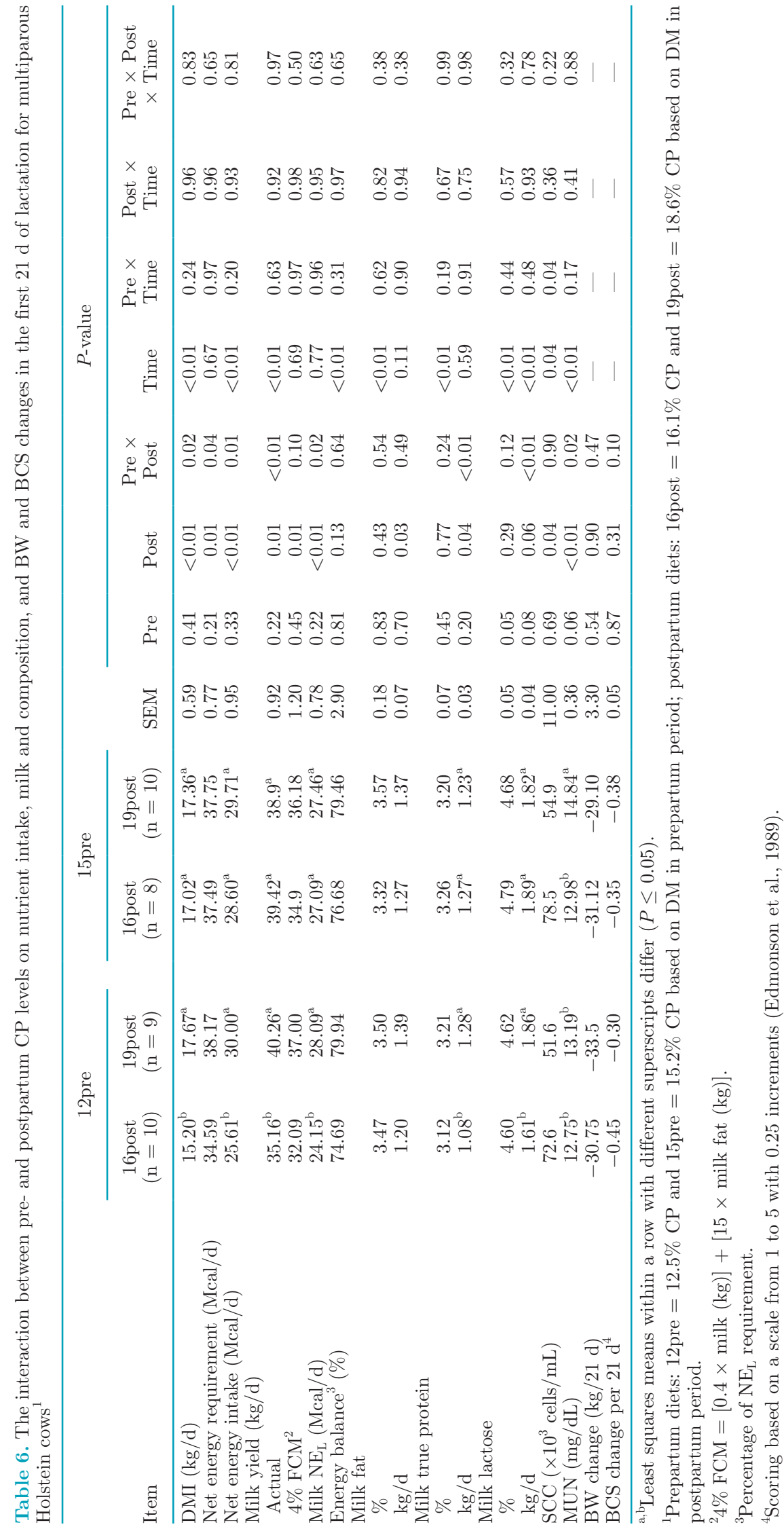




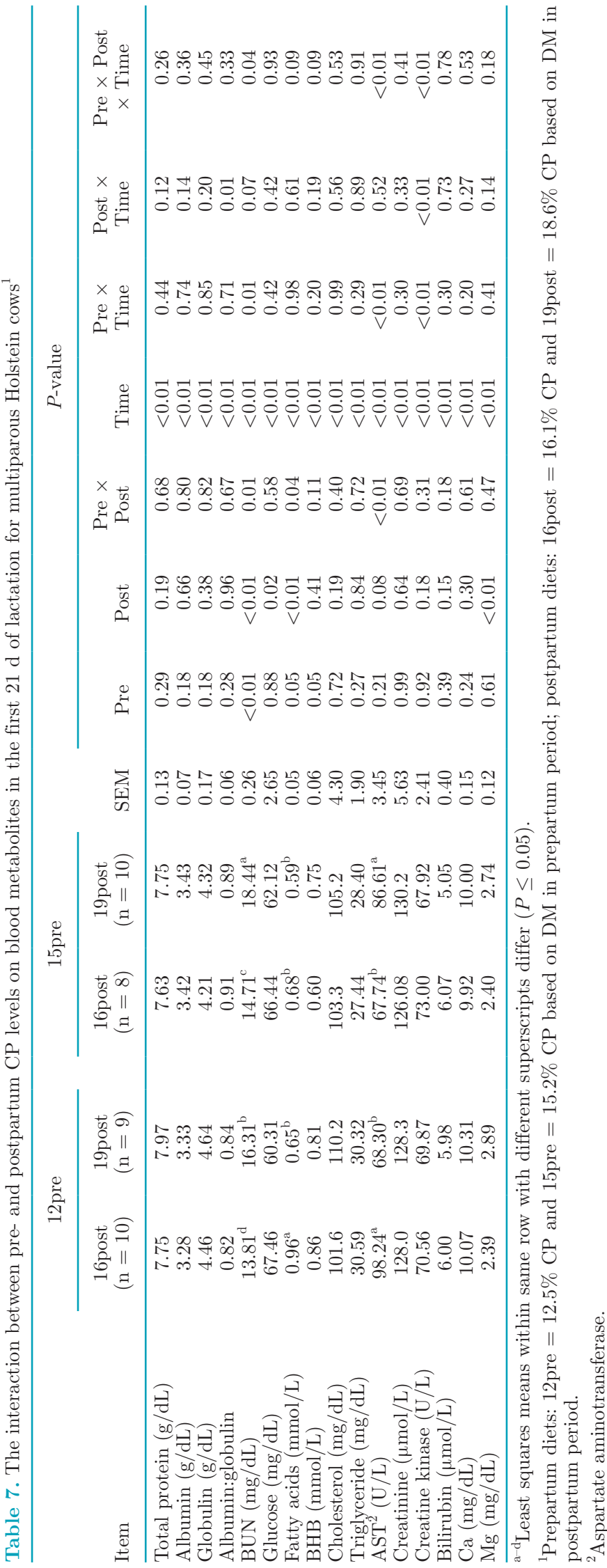

during early lactation period. However, they found a lower BW gain in cows fed an MP-deficient diet than cows fed an MP-adequate diet. This suggests cows exposed to protein-deficient diets depend temporarily on labile protein reserves for supply of AA requirements (Reynolds and Kristensen, 2008).

Milk composition results are presented in Table 6 . The CP levels in prepartum $(P>0.1)$ and postpartum $(P>0.1)$ diets and their interactions $(P>0.1)$ did not affect milk fat and true protein content, except an increase in milk lactose content $(P=0.05)$ when cows were fed 15 pre compared with 12 pre (4.73 vs. $4.61 \%$ ). According to milk yield, feeding 12pre-19post compared with 12pre-16post increased milk true protein $(P<0.01)$ and lactose $(P<0.01)$ yields, but did not differ for cows fed 15pre. In agreement with our results, Larsen et al. (2014) and Amanlou et al. (2017) observed an increase in the yields of milk protein and lactose using additional protein supply during the immediate postpartum period.

Somatic cell count was not affected by the interaction $(P=0.9$; Table 6$)$ between pre- and postpartum CP levels, but feeding 19post compared with 16post reduced SCC during the first $21 \mathrm{~d}$ of lactation $(P=0.04$; Table $6 ; 53.3$ vs. 75.5 cells $\times 10^{3} / \mathrm{mL}$ ). Osorio et al. (2013), in immediate postpartum cows, and Soder and Holden (1999), in mid-lactation cows, reported greater neutrophil phagocytosis and T-lymphocyte proliferation in vitro, respectively, in cows supplemented with Met compared with control cows. Therefore, it is likely that greater AA supply, in particular Met, using RUP sources plays an important role in immune responses during the transition period.

The concentration of MUN was influenced by the interaction between pre- and postpartum CP levels $(P$ $=0.02$; Table 6 ): elevating dietary $\mathrm{CP}$ from 16 post to 19post increased MUN concentrations in 15pre but not in 12pre. These observations are in agreement with other studies (Kauffman and St-Pierre, 2001; Nousiainen et al., 2004), indicating a strong correlation between dietary $\mathrm{CP}$ content and MUN concentrations.

$B W, B C S$, and $E B$. Body weight and BCS changes were not affected by any model components $(P>0.05$; Table 6). However, we observed a tendency $(P=0.1$; Table 6) for an interaction between pre- and postpartum CP levels on BCS change, as 12pre-19post cows tended to have smaller BCS losses than 12pre-16post cows. The 12pre-19post cows had greater energy intake $(P=0.01$; Table 6$)$ and milk $\mathrm{NE}_{\mathrm{L}}(P=0.02$; Table 6$)$ than 12pre-16post. But EB was not affected by dietary CP levels prepartum $(P=0.81$; Table 6$)$ or postpartum $(P=0.13$; Table 6$)$, and their interaction was not significant $(P=0.64$; Table 6$)$. These findings are consistent with BCS and BW change results. In addition, 
other studies investigating the effect of increasing $\mathrm{CP}$ content immediately postpartum did not find changes in BW (Carder and Weiss, 2017) or BCS (Carder and Weiss, 2017) during the postpartum period. In contrast, Giallongo et al. (2015) reported that cows gained less $\mathrm{BW}$ on an MP-deficient diet compared with an MPadequate diet (1.09 vs. $19.7 \mathrm{~kg}$ ) during early lactation. However, in our experiment, the insufficient levels of dietary $\mathrm{CP}$ in 12pre-16post cows resulted in decreased milk yield without any effect on BW.

Blood Metabolites. The interactions of pre- and postpartum CP levels with serum metabolites during the first $21 \mathrm{~d}$ of lactation are presented in Table 7 . There was no interaction between pre- and postpartum CP levels on the serum concentrations of total protein $(P=0.68)$, albumin $(P=0.80)$, globulin $(P=0.82)$, or albumin:globulin ratio $(P=0.67)$.

An interaction between pre- and postpartum CP levels was observed for BUN $(P=0.01)$. Concentrations of BUN were elevated when dietary $\mathrm{CP}$ increased from 16 post to 19 post in both 12 pre and 15 pre cows. The interaction of CP levels in pre- and postpartum by time indicated that cows fed 12pre-19post had higher BUN than those fed 12pre-16post at 3, 7, 14, and 21 DIM. Likewise, cows fed the 15pre-19post diet had higher BUN than those fed 15pre-16post at $0,3,7,14$, and 21 DIM $(P=0.04$; Figure 1$)$.

These results are in agreement with other studies (Larsen et al., 2014; Amanlou et al., 2017; Barros et al., 2017), which showed that differences in BUN and MUN concentrations reflect changes in dietary $\mathrm{CP}$ and $\mathrm{N}$ intake. In addition, it has been reported that exposing hepatocytes to fatty acids in vitro reduces liver urea synthesis (Strang et al., 1998). Bertoni et al. (2008) found that cows with lower liver activity had reduced blood urea concentrations. Therefore, decreased fatty acid concentrations associated with increased BUN concentrations within normal physiological levels for 19 post compared with 16 post cows in both 12pre and 15pre (Table 7) suggest a normal liver activity in these cows.

Serum glucose concentrations were not affected by the interaction between pre- and postpartum CP levels $(P=0.58)$. However, increasing prepartum $\mathrm{CP}$ levels did not affect serum glucose postpartum $(P=0.88)$; increasing CP levels from 16post to 19post reduced postpartum glucose concentrations $(P=0.02$; Table 7$)$. Similarly, Socha et al. (2005) observed lower plasma glucose concentrations in cows supplemented with rumen-protected Lys and Met in the first 2 wk of postpartum compared with unsupplemented cows. They suggested that lower concentrations of glucose might be related to $2.8 \mathrm{~kg} / \mathrm{d}$ greater ECM yield in supplemented

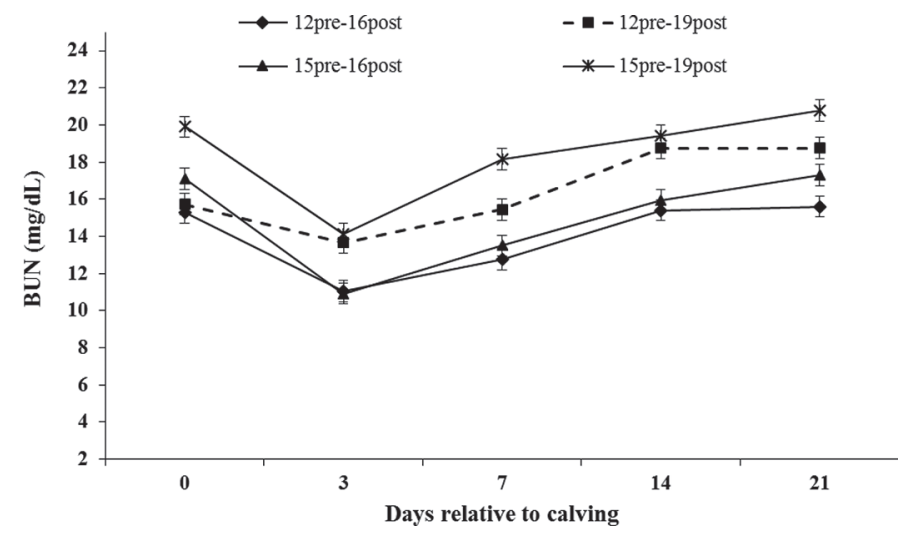

Figure 1. The interaction between pre- and postpartum CP levels on BUN concentrations during the postpartum period. Diets: 12 pre16 post $=12.5 \% \mathrm{CP}$ prepartum and $16.1 \% \mathrm{CP}$ postpartum $(\checkmark ; \mathrm{n}=$ $10) ; 12$ pre-19post $=12.5 \% \mathrm{CP}$ prepartum and $18.6 \% \mathrm{CP}$ postpartum $(\mathbf{\square} ; \mathrm{n}=9)$; 15 pre-16post $=15.2 \% \mathrm{CP}$ prepartum and $16.1 \% \mathrm{CP}$ postpartum $(\mathbf{\Delta} ; \mathrm{n}=8) ; 15$ pre-19post $=15.2 \% \mathrm{CP}$ prepartum and $18.6 \% \mathrm{CP}$ postpartum $(* ; \mathrm{n}=10)$. Data are presented as least squares means and SEM. Pre, $P<0.01$; post, $P<0.01$; pre $\times$ post, $P=0.01$; time, $P<0.01$; pre $\times$ time, $P=0.01$; post $\times$ time, $P=0.07$; pre $\times$ post $\times$ time, $P=0.04$.

cows. In the present study, cows fed 19post produced $2.3 \mathrm{~kg} / \mathrm{d}$ more milk and $90 \mathrm{~g} / \mathrm{d}$ greater lactose than cows fed 16post (Table 6). Therefore, increases in the yields of milk and lactose may account, in part, for the decreases in serum glucose concentration in 19post cows. In contrast to our results, some studies found no effects on glucose concentrations when the supply of protein (Law et al., 2009; Cabrita et al., 2011; Giallongo et al., 2016) or AA (Osorio et al., 2013; Giallongo et al., 2015) was increased.

There was an interaction between pre- and postpartum CP levels for serum fatty acids concentrations postpartum $(P=0.04)$; 12pre-19post cows had lower serum fatty acids than 12pre-16post cows but serum fatty acids did not differ for the 15 pre diet. The 3 -way interactions showed that serum fatty acid concentrations were higher for cows fed a lower dietary CP level both pre- and postpartum at 0,3 , and 7 DIM across dietary treatments $(P=0.09$; Figure 2$)$.

These results are supported by smaller BCS losses (Table 6) in these treatments. In contrast, recent studies have shown an increase in the concentrations of blood fatty acids and glycerol through abomasal AA (Galindo et al., 2015) or casein (Larsen et al., 2014) infusion or soybean meal inclusion (Brown and Allen, 2013). This might be a result of increased milk yield and FCM, along with unchanged or decreased feed intake. In the present study, the increased DMI and energy intake in 12pre-19post cows compared with 12pre-16post cows could reduce lipid mobilization. 


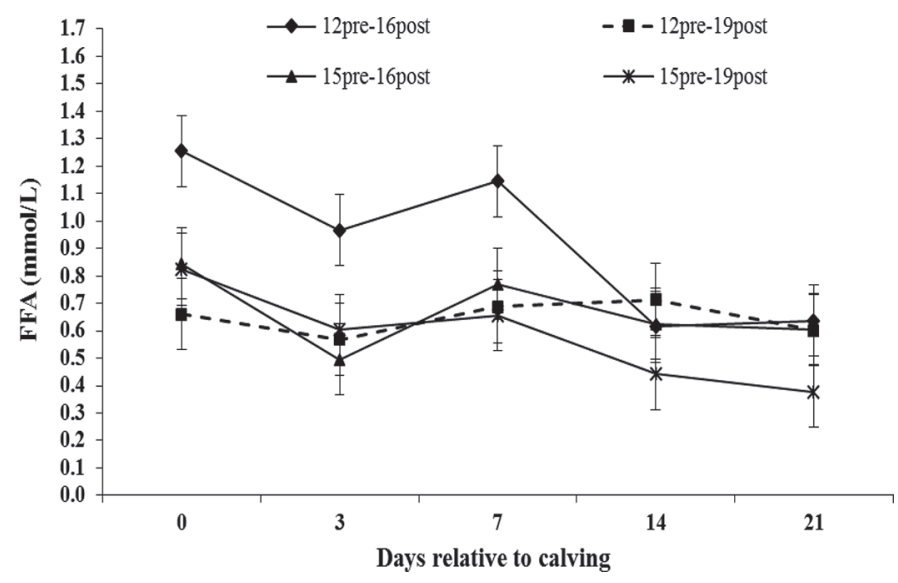

Figure 2. The interaction between pre- and postpartum CP levels on free fatty acids (FFA) concentrations during the postpartum period. Diets: 12 pre-16post $=12.5 \% \mathrm{CP}$ prepartum and $16.1 \% \mathrm{CP}$ postpartum $(\diamond ; \mathrm{n}=10) ; 12$ pre-19post $=12.5 \% \mathrm{CP}$ prepartum and $18.6 \% \mathrm{CP}$ postpartum $(\mathbf{\square} ; \mathrm{n}=9) ; 15$ pre-16post $=15.2 \% \mathrm{CP}$ prepartum and $16.1 \% \mathrm{CP}$ postpartum $(\mathbf{\Lambda} ; \mathrm{n}=8) ; 15$ pre-19post $=15.2 \% \mathrm{CP}$ prepartum and $18.6 \% \mathrm{CP}$ postpartum $(* ; \mathrm{n}=10)$. Data are presented as least squares means and SEM. Pre, $P=0.05$; post, $P<0.01$; pre $\times$ post, $P=0.04$; time, $P<0.01$; pre $\times$ time, $P=0.98$; post $\times$ time, $P$ $=0.61 ;$ pre $\times$ post $\times$ time, $P=0.09$.

Serum concentrations of BHB were not affected by the interaction between pre- and postpartum CP levels $(P=0.11)$. However, increasing prepartum dietary $\mathrm{CP}$ levels reduced postpartum BHB concentrations $(P=$ $0.05 ; 0.67$ vs. $0.83 \mathrm{mmol} / \mathrm{L}$; Table 7 ), similar to our previous findings (Amirabadi Farahani et al., 2017). In contrast to our findings, others (Greenfield et al., 2000; Hartwell et al., 2000; Park et al., 2002) did not report any effects of feeding prepartum protein on fatty acids and BHB concentrations, because DMI and milk yield were not affected in those studies. The 3-way interactions showed that serum BHB concentrations were higher for cows fed lower CP levels both pre- and postpartum at 0 and 3 DIM across dietary treatments $(P=0.09$; Figure 3$)$.

There was an interaction between pre- and postpartum CP levels on serum AST concentration $(P<0.01)$. Concentrations of serum AST decreased inversely with dietary CP levels in postpartum cows for 12pre. However, increasing dietary CP levels from 16post to 19post in 15pre cows increased serum AST concentrations. Interaction of CP levels in pre- and postpartum by time indicated that cows fed 12pre-19post had lower serum AST concentrations than those fed 12pre-16post at 3, 7, 14, and 21 DIM. In contrast, cows fed 15pre-19post had higher serum AST concentrations than those fed 15pre-16post at 3, 14, and 21 DIM $(P<0.01$; Figure 4$)$. According to positive correlations between plasma fatty acids concentrations and AST activity (Chamberlin et al., 2013), the decreased AST in 12pre-19post

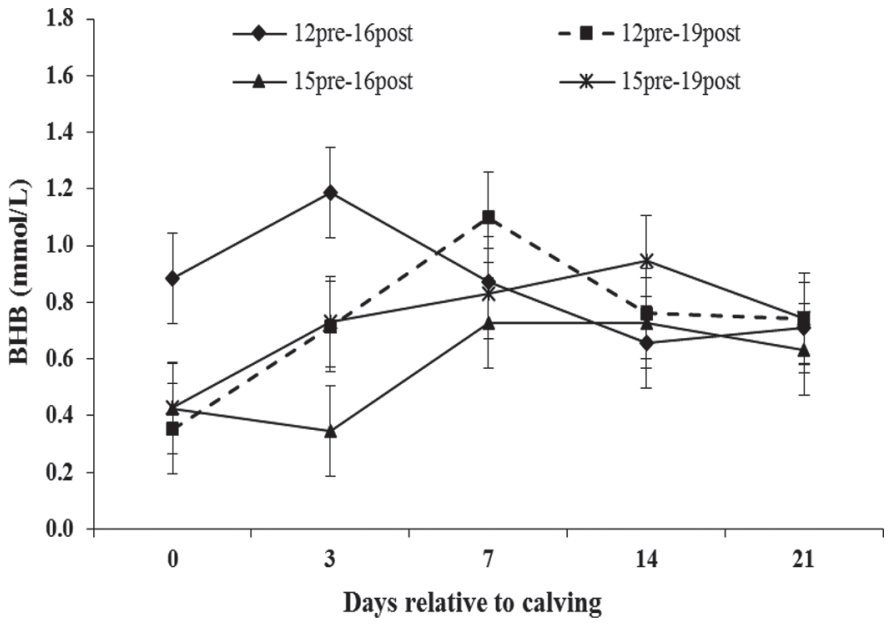

Figure 3. The interaction between pre- and postpartum CP levels on BHB concentrations during the postpartum period. Diets: 12pre16 post $=12.5 \% \mathrm{CP}$ prepartum and $16.1 \% \mathrm{CP}$ postpartum $(\checkmark ; \mathrm{n}=$ $10) ; 12$ pre-19post $=12.5 \% \mathrm{CP}$ prepartum and $18.6 \% \mathrm{CP}$ postpartum $(\mathbf{\square} ; \mathrm{n}=9) ; 15$ pre-16post $=15.2 \% \mathrm{CP}$ prepartum and $16.1 \% \mathrm{CP}$ postpartum $(\mathbf{\Lambda} ; \mathrm{n}=8) ; 15$ pre-19post $=15.2 \% \mathrm{CP}$ prepartum and $18.6 \% \mathrm{CP}$ postpartum $(* ; \mathrm{n}=10)$. Data are presented as least squares means and SEM. Pre, $P=0.05$; post, $P=0.41$; pre $\times$ post, $P=0.11$; time, $P<0.01$; pre $\times$ time, $P=0.20$; post $\times$ time, $P=0.19$; pre $\times$ post $\times$ time, $P=0.09$.

compared with 12pre-16post was expected. Even though serum fatty acids concentrations were not different between 15pre-19post and 15pre-16post, serum

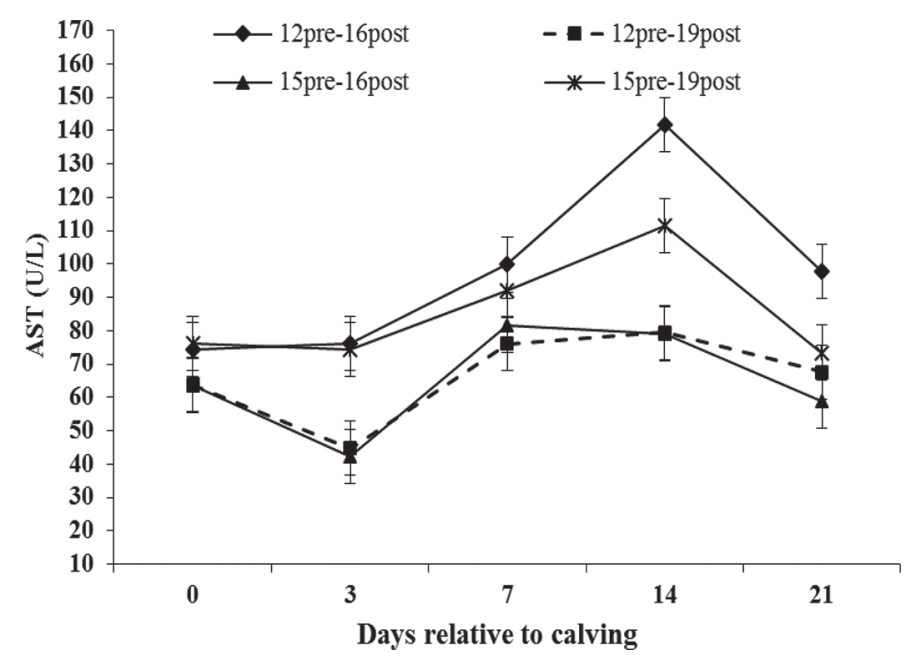

Figure 4. The interaction between pre- and postpartum CP levels on aspartate aminotransferase (AST) concentrations during the postpartum period. Diets: 12 pre-16post $=12.5 \% \mathrm{CP}$ prepartum and $16.1 \%$ $\mathrm{CP}$ postpartum $(\diamond ; \mathrm{n}=10) ; 12$ pre-19post $=12.5 \% \mathrm{CP}$ prepartum and $18.6 \%$ CP postpartum $(\mathbf{\square} ; \mathrm{n}=9) ; 15$ pre-16post $=15.2 \% \mathrm{CP}$ prepartum and $16.1 \% \mathrm{CP}$ postpartum $(\mathbf{\Lambda} ; \mathrm{n}=8) ; 15$ pre-19post $=15.2 \% \mathrm{CP}$ prepartum and $18.6 \% \mathrm{CP}$ postpartum $(* ; \mathrm{n}=10)$. Data are presented as least squares means and SEM. Pre, $P=0.21$; post, $P=0.08$; pre $\times$ post, $P<0.01$; time, $P<0.01$; pre $\times$ time, $P<0.01$; post $\times$ time, $P$ $=0.52$; pre $\times$ post $\times$ time, $P<0.01$. 
AST concentrations were higher in 15pre-19post. Although this might suggest impaired liver function in these cows, serum AST concentrations were within the range expected for peripartal cows (Bertoni et al., 2008; Graugnard et al., 2012).

Concentrations of serum creatinine and creatine kinase were not affected by any model components $(P>$ 0.1). Increasing dietary CP levels from 16post to 19post in 15pre cows did not affect creatine kinase concentrations from calving to 21 DIM, but serum creatine kinase decreased at 7 DIM in 12pre cows. Overall, the 3 -way interactions showed that cows fed 15pre had less serum creatine kinase variation during the postpartum period than cows fed 12pre $(P<0.01$; Figure 5$)$.

These observations are consistent with $\mathrm{BW}$ changes of cows in all treatments, because serum creatinine concentration is directly related to BW, muscle mass, and muscle proteolysis (Perrone et al., 1992; Shahzad et al., 2014). Our results are in agreement with others that did not report any effects of different MP levels on creatinine (Giallongo et al., 2015) or creatinine and creatine kinase (Giallongo et al., 2016) concentrations. Additionally, Ji and Dann (2013) found no effect of additional supply of protein on the plasma concentration of 3-methyl-histidine, an indicator of protein tissue catabolism, or the expression of genes involved in skeletal muscle protein degradation during early lactation. In the present study, feeding additional protein did not

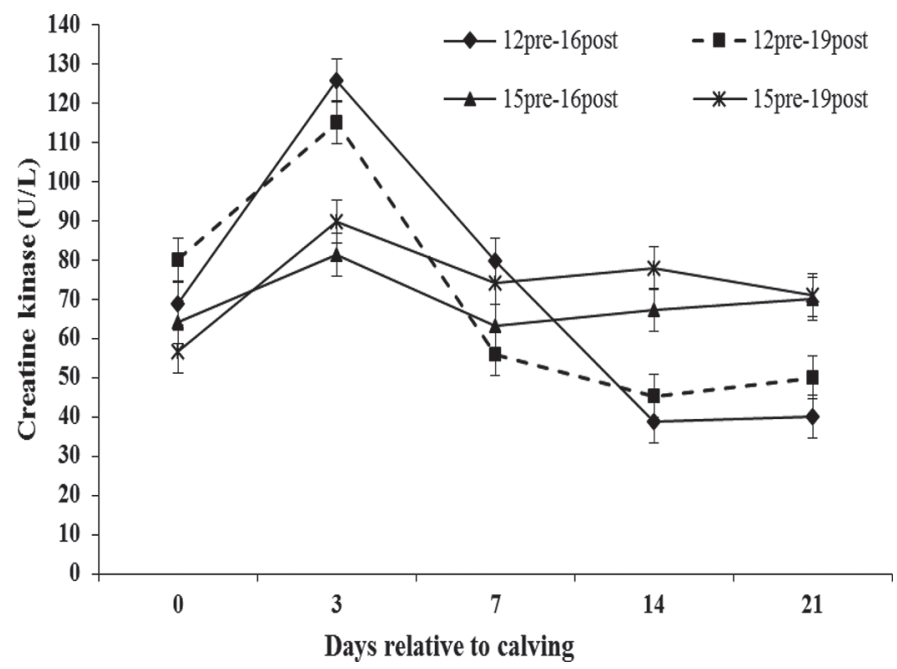

Figure 5. The interaction between pre- and postpartum CP levels on creatine kinase concentrations during the postpartum period. Diets: 12pre-16post $=12.5 \% \mathrm{CP}$ prepartum and $16.1 \% \mathrm{CP}$ postpartum $(\bullet$; $\mathrm{n}=10) ; 12$ pre-19post $=12.5 \% \mathrm{CP}$ prepartum and $18.6 \% \mathrm{CP}$ postpartum $(\square ; \mathrm{n}=9) ; 15$ pre-16post $=15.2 \% \mathrm{CP}$ prepartum and $16.1 \%$ $\mathrm{CP}$ postpartum $(\boldsymbol{\Delta} ; \mathrm{n}=8) ; 15$ pre-19post $=15.2 \% \mathrm{CP}$ prepartum and $18.6 \% \mathrm{CP}$ postpartum $(* ; \mathrm{n}=10)$. Data are presented as least squares means and SEM. Pre, $P=0.92$; post, $P=0.18$; pre $\times$ post, $P=0.31$; time, $P<0.01$; pre $\times$ time, $P<0.01$; post $\times$ time, $P<0.01$; pre $\times$ post $\times$ time, $P<0.01$. spare mobilization of protein from body reserves but instead increased milk yield.

The serum concentration of bilirubin was not affected by treatments $(P=0.18)$, similar to observations by Osorio et al. (2014), who reported Met supplementation had no effect on bilirubin concentration during the periparturient period. Concentrations of cholesterol and triglyceride were not affected by any model components $(P>0.1)$.

The interaction between pre- and postpartum CP levels did not affect $\mathrm{Ca}(P=0.61)$ or $\mathrm{Mg}(P=0.47)$ concentrations postpartum, but increasing dietary $\mathrm{CP}$ levels during the postpartum period increased serum $\mathrm{Mg}$ concentration $(2.81$ vs. $2.40 \mathrm{mg} / \mathrm{dL} ; P<0.01)$. Unlike $\mathrm{Ca}$, there is no known hormonal mechanisms to maintain the blood concentration of $\mathrm{Mg}$, and its concentration depends on $\mathrm{Mg}$ intake and absorption from the gastrointestinal tract (Martín-Tereso and Martens, 2014). It is likely that increased serum $\mathrm{Mg}$ concentrations in 19post compared with 16post cows was a result of increased DMI (17.51 vs. $16.11 \mathrm{~kg} / \mathrm{d}$; Table 6) in the postpartum period.

\section{CONCLUSIONS}

Increasing dietary CP postpartum from 16 to $19 \%$ of DM increased DMI and milk yield and reduced serum fatty acids for cows fed $12 \% \mathrm{CP}$ prepartum. However, these responses were not observed in cows fed $15 \% \mathrm{CP}$ prepartum, suggesting that dietary $\mathrm{CP}$ postpartum could be decreased to $16 \%$ of DM when cows are fed higher dietary CP prepartum. Increasing CP levels from 12 to $15 \%$ of DM prepartum decreased serum BHB concentration postpartum. Feeding increased CP levels postpartum decreased milk SCC. Because of the potential to decrease SCC, the effects of additional protein supply using RUP supplements immediately after calving on immune system warrant further investigation.

\section{ACKNOWLEDGMENTS}

This research was supported by FKA Co. (Isfahan, Iran). The authors gratefully acknowledge J. Jalilnejad (FKA Co.) for facilitating the present study and his financial support. The authors acknowledge farm veterinarians and experts for their invaluable assistance in conducting this experiment.

\section{REFERENCES}

Adachi, N., T. Kusuhara, I. Nonaka, and F. Terada. 2006. Effect of close-up dry period protein level on preparturiental nitrogen balance and lactating performance of primigravid and multiparous Holstein cows. Asian-australas. J. Anim. Sci. 19:831-836. 
Allen, M. S., B. J. Bradford, and M. Oba. 2009. The hepatic oxidation theory of the control of feed intake and its application to ruminants. J. Anim. Sci. 87:3317-3334.

Amanlou, H., A. P. Akbari, N. E. Farsuni, and N. Silva-del-Rio. 2016. Effects of subcutaneous calcium administration at calving on mineral status, health, and production of Holstein cows. J. Dairy Sci. 99:9199-9210.

Amanlou, H., T. Amirabadi Farahani, and N. Eslamian Farsuni. 2017. Effects of rumen undegradable protein supplementation on productive performance and indicators of protein and energy metabolism in Holstein fresh cows. J. Dairy Sci. 100:3628-3640.

Amirabadi Farahani, T., H. Amanlou, and M. Kazemi-Bonchenari. 2017. Effects of shortening the close-up period length coupled with increased supply of metabolizable protein on performance and metabolic status of multiparous Holstein cows. J. Dairy Sci. 100:6199-6217.

AOAC. 1990. Official Methods of Analysis. 15th ed. Association of Official Analytical Chemists, Arlington, VA.

Barros, T., M. A. Quaassdorff, M. A. Aguerre, J. J. Olmos Colmenero, S. J. Bertics, P. M. Crump, and M. A. Wattiaux. 2017. Effects of dietary crude protein concentration on late-lactation dairy cow performance and indicators of nitrogen utilization. J. Dairy Sci. 100:5434-5448.

Bell, A. W. 1995. Regulation of organic nutrient metabolism during transition from late pregnancy to early lactation. J. Anim. Sci. 73:2804-2819.

Bell, A. W., W. S. Burhans, and T. R. Overton. 2000. Protein nutrition in late pregnancy, maternal protein reserves and lactation performance in dairy cows. Proc. Nutr. Soc. 59:119-126.

Bergmeyer, H. U., M. Herder, and R. Ref. 1986. International Federation of Clinical Chemistry (IFCC). J. Clin. Chem. Clin. Biochem. 24:497-510.

Bertoni, G., E. Trevisi, X. Han, and M. Bionaz. 2008. Effects of inflammatory conditions on liver activity in puerperium period and consequences for performance in dairy cows. J. Dairy Sci. 91:33003310 .

Brown, W. E., and M. S. Allen. 2013. Effects of intrajugular glucose infusion on feed intake, milk yield, and metabolic responses of early postpartum cows fed diets varying in protein and starch concentration. J. Dairy Sci. 96:7132-7142.

Cabrita, A. R. J., R. J. Dewhurst, D. S. P. Melo, J. M. Moorby, and A. J. M. Fonseca. 2011. Effects of dietary protein concentration and balance of absorbable amino acids on productive responses of dairy cows fed corn silage-based diets. J. Dairy Sci. 94:4647-4656.

Carder, E. G., and W. P. Weiss. 2017. Short- and longer-term effects of feeding increased metabolizable protein with or without an altered amino acid profile to dairy cows immediately postpartum. J. Dairy Sci. 100:4528-4538.

Chamberlin, W. G., J. Middleton, J. Spain, G. Johnson, M. Ellersieck, and P. Pithua. 2013. Subclinical hypocalcemia, plasma biochemical parameters, lipid metabolism, postpartum disease, and fertility in postparturient dairy cows. J. Dairy Sci. 96:7001-7013.

Doepel, L., H. Lapierre, and J. Kennelly. 2002. Peripartum performance and metabolism of dairy cows in response to prepartum energy and protein intake. J. Dairy Sci. 85:2315-2334.

Edmonson, A., I. Lean, L. Weaver, T. Farver, and G. Webster. 1989 A body condition scoring chart for Holstein dairy cows. J. Dairy Sci. 72:68-78.

Galindo, C., M. Larsen, D. R. Ouellet, G. Maxin, D. Pellerin, and H. Lapierre. 2015. Abomasal amino acid infusion in postpartum dairy cows: Effect on whole-body, splanchnic, and mammary glucose metabolism. J. Dairy Sci. 98:7962-7974.

Giallongo, F., M. T. Harper, J. Oh, J. C. Lopes, H. Lapierre, R. A. Patton, C. Parys, I. Shinzato, and A. N. Hristov. 2016. Effects of rumen-protected methionine, lysine, and histidine on lactation performance of dairy cows. J. Dairy Sci. 99:4437-4452.

Giallongo, F., A. N. Hristov, J. Oh, T. Frederick, H. Weeks, J. Werner, H. Lapierre, R. A. Patton, A. Gehman, and C. Parys. 2015. Effects of slow-release urea and rumen-protected methionine and histidine on performance of dairy cows. J. Dairy Sci. 98:3292-3308.
Graugnard, D. E., M. Bionaz, E. Trevisi, K. M. Moyes, J. L. SalakJohnson, R. L. Wallace, J. K. Drackley, G. Bertoni, and J. J. Loor. 2012. Blood immunometabolic indices and polymorphonuclear neutrophil function in peripartum dairy cows are altered by level of dietary energy prepartum. J. Dairy Sci. 95:1749-1758.

Greenfield, R. B., M. Cecava, T. Johnson, and S. Donkin. 2000. Impact of dietary protein amount and rumen undegradability on intake, peripartum liver triglyceride, plasma metabolites, and milk production in transition dairy cattle. J. Dairy Sci. 83:703-710.

Hartwell, J. R., M. Cecava, and S. Donkin. 2000. Impact of dietary rumen undegradable protein and rumen-protected choline on intake, peripartum liver triacylglyceride, plasma metabolites and milk production in transition dairy cows. J. Dairy Sci. 83:2907-2917.

Hook, T. E., K. G. Odde, A. A. Aguilar, and J. D. Olson. 1989. Protein effects on fetal growth, colostrum and calf immunoglobulins and lactation in dairy heifers. J. Anim. Sci. 67(Suppl. 1):539. (Abstr.)

Huyler, M. T., R. Kincaid, and D. Dostal. 1999. Metabolic and yield responses of multiparous Holstein cows to prepartum rumen-undegradable protein. J. Dairy Sci. 82:527-536.

Ji, P., and H. M. Dann. 2013. Negative protein balance: Implications for transition cows. Pages 101-112 in Proc. Cornell. Nutr. Conf., Ithaca, NY. Cornell University, Ithaca, NY.

Jonker, J. S., R. Kohn, and R. Erdman. 1998. Using milk urea nitrogen to predict nitrogen excretion and utilization efficiency in lactating dairy cows. J. Dairy Sci. 81:2681-2692.

Kauffman, A. J., and N. R. St-Pierre. 2001. The relationship of milk urea nitrogen to urine nitrogen excretion in Holstein and Jersey cows. J. Dairy Sci. 84:2284-2294.

Larsen, M., H. Lapierre, and N. B. Kristensen. 2014. Abomasal protein infusion in postpartum transition dairy cows: Effect on performance and mammary metabolism. J. Dairy Sci. 97:5608-5622.

Law, R. A., F. Young, D. Patterson, D. Kilpatrick, A. Wylie, and C Mayne. 2009. Effect of dietary protein content on animal production and blood metabolites of dairy cows during lactation. J. Dairy Sci. 92:1001-1012.

Lean, I. J., R. Van Saun, and P. J. DeGaris. 2013. Energy and protein nutrition management of transition dairy cows. Vet. Clin. North Am. Food Anim. Pract. 29:337-366.

Lee, C., F. Giallongo, A. Hristov, H. Lapierre, T. Cassidy, K. Heyler, G. Varga, and C. Parys. 2015. Effect of dietary protein level and rumen-protected amino acid supplementation on amino acid utilization for milk protein in lactating dairy cows. J. Dairy Sci. 98:1885-1902.

Martín-Tereso, J., and H. Martens. 2014. Calcium and magnesium physiology and nutrition in relation to the prevention of milk fever and tetany (dietary management of macrominerals in preventing disease). Vet. Clin. North Am. Food Anim. Pract. 30:643-670.

Nousiainen, J., K. J. Shingfield, and P. Huhtanen. 2004. Evaluation of milk urea nitrogen as a diagnostic of protein feeding. J. Dairy Sci. $87: 386-398$.

NRC. 2001. Nutrient Requirements of Dairy Cattle. 7th rev. ed. National Academies Press, Washington, DC

Osorio, J. S., P. Ji, J. K. Drackley, D. Luchini, and J. J. Loor. 2013. Supplemental Smartamine M or MetaSmart during the transition period benefits postpartal cow performance and blood neutrophil function. J. Dairy Sci. 96:6248-6263.

Osorio, J. S., E. Trevisi, P. Ji, J. K. Drackley, D. Luchini, G. Bertoni, and J. J. Loor. 2014. Biomarkers of inflammation, metabolism, and oxidative stress in blood, liver, and milk reveal a better immunometabolic status in peripartal cows supplemented with Smartamine M or MetaSmart. J. Dairy Sci. 97:7437-7450.

Park, A. F., J. Shirley, E. Titgemeyer, M. Meyer, M. VanBaale, and M. VandeHaar. 2002. Effect of protein level in prepartum diets on metabolism and performance of dairy cows. J. Dairy Sci. 85:18151828.

Perrone, R. D., N. E. Madias, and A. S. Levey. 1992. Serum creatinine as an index of renal function: New insights into old concepts. Clin. Chem. 38:1933-1953.

Reynolds, C. K., and N. B. Kristensen. 2008. Nitrogen recycling through the gut and the nitrogen economy of ruminants: An asynchronous symbiosis. J. Anim. Sci. 86(E. Suppl.):E293-E305. 
Robinson, P. H., J. Moorby, M. Arana, R. Hinders, T. Graham, L. Castelanelli, and N. Barney. 2001. Influence of close-up dry period protein supplementation on productive and reproductive performance of Holstein cows in their subsequent lactation. J. Dairy Sci. 84:2273-2283

Shahzad, K., M. Bionaz, E. Trevisi, G. Bertoni, S. L. Rodriguez-Zas, and J. J. Loor. 2014. Integrative analyses of hepatic differentially expressed genes and blood biomarkers during the peripartal period between dairy cows overfed or restricted-fed energy prepartum. PLoS One 9:e99757.

Socha, M. T., D. E. Putnam, B. D. Garthwaite, N. L. Whitehouse, N. A. Kierstead, C. G. Schwab, G. A. Ducharme, and J. C. Robert. 2005. Improving intestinal amino acid supply of pre-and postpartum dairy cows with rumen-protected methionine and lysine. J. Dairy Sci. 88:1113-1126.

Soder, K. J., and L. A. Holden. 1999. Lymphocyte proliferation response of lactating dairy cows fed varying concentrations of rumen protected methionine. J. Dairy Sci. 82:1935-1942.

Strang, B. D., S. Bertics, R. Grummer, and L. Armentano. 1998. Effect of long-chain fatty acids on triglyceride accumulation, gluco- neogenesis, and ureagenesis in bovine hepatocytes. J. Dairy Sci 81:728-739.

van der Drift, S. G. A., M. Houweling, J. T. Schonewille, A. G. M. Tielens, and R. Jorritsma. 2012. Protein and fat mobilization and associations with serum $\beta$-hydroxybutyrate concentrations in dairy cows. J. Dairy Sci. 95:4911-4920.

Van Saun, R. J. 1993. Effects of undegradable protein fed prepartum on subsequent lactation, reproduction, and health in Holstein dairy cattle. PhD Thesis. Department of Animal Science, Cornell University, Ithaca, NY.

Van Soest, P. J., J. B. Robertson, and B. A. Lewis. 1991. Methods for dietary fiber, neutral detergent fiber, and nonstarch polysaccharides in relation to animal nutrition. J. Dairy Sci. 74:3583-3597.

Vandehaar, M. J., G. Yousif, B. Sharma, T. Herdt, R. Emery, M. Allen, and J. Liesman. 1999. Effect of energy and protein density of prepartum diets on fat and protein metabolism of dairy cattle in the periparturient period. J. Dairy Sci. 82:1282-1295. 